\title{
Flatbrød til folket
}

Det var harde kår i Norge i 1920-årene, og ett av de mange problemene nordmenn måtte bryne seg på var at produksjonsmetodene for flatbrød var dårlig egnet for masseproduksjon. Folkehelseforeningen utlyste i 1920 en konkurranse for å finne frem til den «bedste fabrikmæssige fremstilling av flatbrød utelukkende av norsk korn». Mannen som til slutt gikk av med seieren, Nils Halvorsen, hadde visstnok latt seg inspirere av sin tid som reparatør av cellulosemaskiner ved Skiens Cellulosefabrikk. Alle som har befunnet seg på E18 ved Tønsberg kjenner igjen landemerket denne fabrikken utviklet seg til å bli. Korni-fabrikken holdt det gående i nesten 100 år før den ble nedlagt i 2013, og Korni flatbrød er et av de mest ikoniske produkter som var å finne i norske hjem. Konkurransen ble omtalt i spalten Hygieniske meddelelser og social medicin i Tidsskriftet nr. 3/1921. Skribentens håp om at flatbrød kanskje kunne bli allemannskost også for bybefolkningen, må vel sies å ha blitt innfridd (Tidsskr Nor Lægeforen 1921; 41: 117-8).

Flatbrød fabrikmæssig fremstillet. Vort nationale flatbrød har med rette været anset som et usedvanlig godt, let fordøielig og sundt brød, - ikke mindst fordi det maa antages som velstekt og paa grund av sin sprødhet at ha en gavnlig indvirkning paa tænderne under tygningen (jfr. distriktslæge O. Prydz' artikler i dette tidsskrift: Litt om aarsakerne til nutidens tandsygdommer, 1905, s. 283). Dette brød indeholder jo alle kornets nærende bestanddeler, og da det bakes av vore nationale kornsorter byg og havre, vil en fabrikmæssig fremstilling til billig pris ogsaa spille en stor statsøkonomisk rolle. Folkehelseforeningen fik ifjor istand en præmiekonkurrence om den bedste fabrikmæssige fremstilling av flatbrød utelukkende av norsk korn. Den gamle bakning paa «takker» er altfor besværlig og kostbar, naar flatbrødet skal fremstilles i større mængder til bruk for bybefolkningen. Den nævnte jury, som bestod av prof. S. Torup, doktor E. Møinichen og tandlæge E. Hirsch, utdelte 12te decbr. ifjor førstepræmien paa $3000 \mathrm{kr}$. til eieren av Vestfold flatbrødbakeri, Nils Halvorsen, Barkaaker, som efter 30 aars eksperimentering har konstruert en hensigtsmæssig maskine og fastslaat en bakemaate, som tilfredsstiller alle rimelige krav.

I Folkehelseforeningens lokale blev det nye maskinbakte flatbrød den 15de decbr. ifjor fremvist for og prøvet av endel indbudte, som fandt brødet udmerket. Det oplystes, at under prøvedriften hadde fabriken fremstillet 250 kilo flatbrød pr. dag og i oktober levert 9 tons brød. Ved slik stordrift vil brødet bli billig. Det tykkere frokostflatbrød er beregnet til 54 øre pr. kilo mel og tyndbrødet til 65 øre. Man tør derfor haape, det kan bli allemandskost.

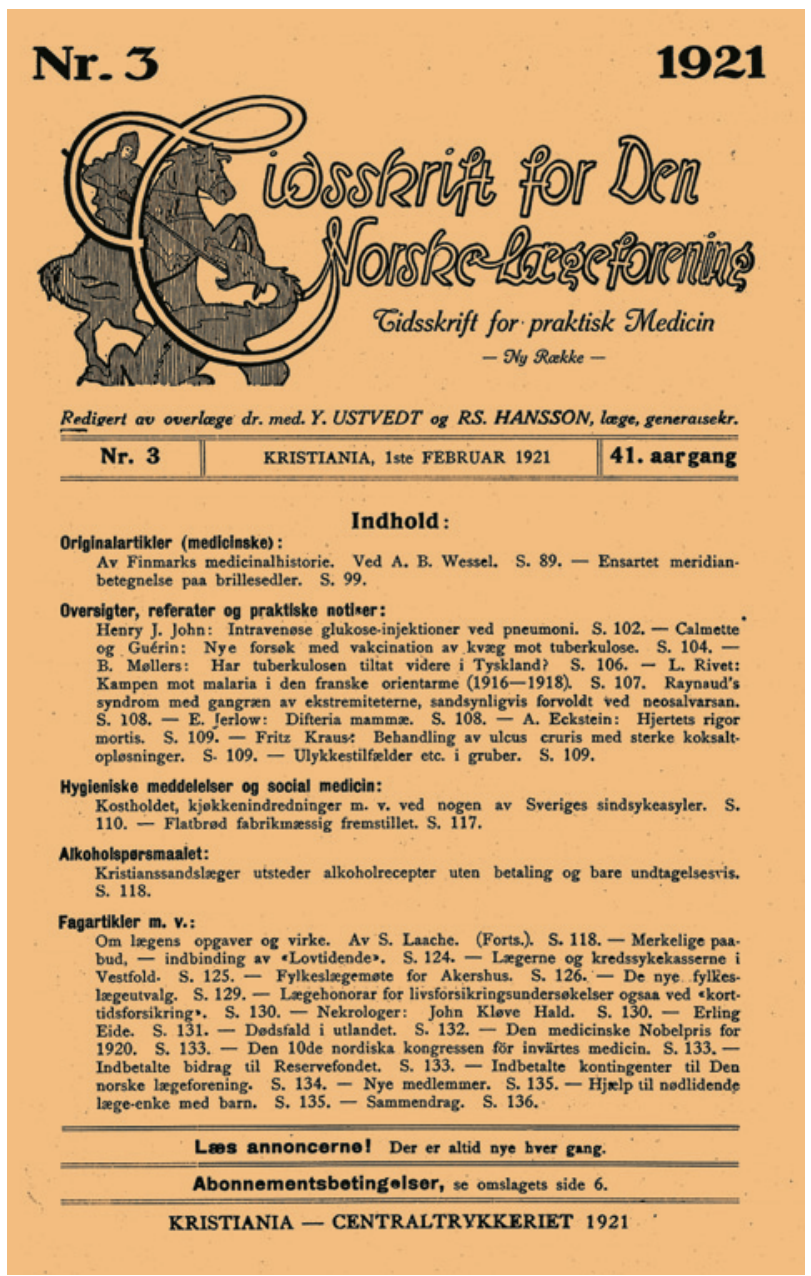

